\title{
Welfare Detection and Legal Effectiveness: Country Institutions Which the Authority is Regulated in Law in the Disputes of Authority
}

\author{
Demas Brian W ${ }^{1}$, Sudarsono ${ }^{2}$, Rachmad Safa'at ${ }^{2}$, Muchamad Ali Safa' at $^{\mathbf{2}}$ \\ ${ }^{1}$ Student in Postgraduate Law Doctoral Program, Faculty of Law, Brawijaya University, Indonesia \\ ${ }^{2}$ Lecturers and Researchers in Postgraduate Law Doctoral Program, Faculty of Law, Brawijaya University, \\ Indonesia \\ demasbrian03@gmail.com
}

\begin{abstract}
Institutional design of the state with separation of powers and checks and balance give birth to the intersection of authority. This condition has the potential to create a power dispute between state institutions. Provisions regarding the resolution of disputes over state institutions are inseparable from issues concerning subjectum and objectum litis which have become jurisprudential and the institution is independent and is not subordinate to other institutions, so there are several state institutions that cannot resolve disputes in the Constitutional Court, namely state institutions that regulate them outside the Constitution, whether regulated by law or under the law. The purpose of this study is to describe the provisions of dispute resolution for the authority of state agencies which the authority is regulated in law. This journal research uses a qualitative paradigm with a phenomenological approach in the translation. The results obtained in this study are: 1) Detection of Welfare which will be realized in maximum when all state agencies effective in operation; 2) Paradigm: Analysis of Dispute Authority of State Institutions. On the basis of a modern legal state, disputes over the authority of state institutions that are formed based on the law, need to be channeled to settle so that they remain based on due process of law and there are no rules in the process of resolving disputes over the authority of state institutions in the law.
\end{abstract}

Keywords welfare; legal effectiveness; institutions; law

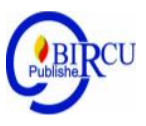

\section{Introduction}

The rapid formation of new state institutions, which are mostly independent state commissions, is a worldwide phenomenon, and is caused by various social and economic changes. This forced many countries to carry out institutional experimentation through the establishment of various organs countries that are considered more effective, efficient, powerful, and of course. This institutional experimentation achieved success in several countries, such as the United States, United Kingdom, and France, but also failed, as in Brazil. It is said to have failed because the rapid formation of the new state institutions was not well designed, so what happened was called deadlocked democracy ${ }^{1}$. The characteristics of this hampered democracy are ineffective governance, and low accountability. Its formation is very rapid, not accompanied by a discrepancy in the role of a large bureaucracy, so that it is not resulting in inefficiency but adds to inefficiency

\footnotetext{
${ }^{1}$ Lukman Hakim, 2010. Legal Status of the State Commission in Indonesia, Postgraduate Program in Brawijaya University Malang, Puskasi Universitas Widyagama Malang, and 10 Equivalent Press, Malang, pp. 226
}

DOI: https://doi.org/10.33258/birci.v3i1.739 
because it increases the burden on the state budget and increases the number of government personnel. Some of them are ad hoc in nature, meaning that there are so many of them, that the time is up, the institution has not or has not been paid from being disbanded, while the administrators continue to budget the state revenue and regional expenditure ${ }^{2}$.

In the Indonesian context, in my opinion, it is still too premature to say that the formation of new state institutions, which are mostly independent state institutions, have failed or succeeded. It is more correct to say that the related formation shows "limited success," because the achievements achieved today do indeed provide an atmosphere of democratic state rule (democratische rechtsstaat), which was so coveted by the Indonesian people in the New Order era, but still did not produce the efficiency and effectiveness as it had expected to realize good governance, and moreover to realize the goals of the country ${ }^{3}$. Therefore accommodating to the demands of the people. According to Husda, 2018) the institutions cover various fields of life that are constantly evolving from time to time. There are institutions that are very close to the beliefs that are followed, so that they have a very high level of sensitivity, such as worship institutions, kinship institutions and educational institutions. There is also a relatively far from belief, so it is relatively flexible or "neutral" like an economic institution. Furthermore, the institution experienced concretization in the structure of society in the form of various social organizations as a vehicle for meeting life's needs in a collective and planned manner.

In the Indonesian context, the economic changes referred to are uncontrolled price inflation, and the low exchange rate (exchange rate) of the rupiah against foreign currencies, especially the US dollar, while social change as described earlier is a reform movement. The reform movement is a noble agreement of the nation, which forms the basis of the amendments to the 1945 Constitution, and is the womb for the formation of an independent state commission. Therefore, the existence of the KNI and the noble aims of establishing it cannot be separated from the reform movement. Furthermore, in the Indonesian context, Firmansyah Arifin stated that there were a number of things that were at the core and influenced many of the formation of new independent state institutions (independent state institutions). These things include:

1. Lack of credibility of existing state institutions due to the assumption of systemic, entrenched and difficult corruption to be eradicated. No independence of existing state institutions.

2. Because each other is only subject to the influence of one state or other power.

3. The inability of existing state institutions to carry out urgent tasks is carried out during the transition to democracy because of bureaucratic and KKN problems.

4. Global influence, with the formation of so-called auxiliary organ state agencies or watchdog institutions in many countries.

5. Pressure from international institutions, not only as a prerequisite for entering the global market, but also to make democracy the only way for a country whose origins are under authoritarian rule ${ }^{4}$.

\footnotetext{
2 Jimly Asshiddigie, 2009, Pengantar ilmu Hukum Tata Negara, Rajawali Pers, Jakarta, pp. 341

${ }^{3}$ The goals of the Republic of Indonesia are; (1) To protect the entire Indonesian nation and all Indonesian blood spills; (2) promote public welfare; (3) educating the life of the nation; and (4) participate in carrying out world order based on independence, eternal peace and social justice.

${ }^{4}$ Firmansvah Arifin, et all, 2005, State Institutions and Disputes Authority of State Institutions, National Law Reform Consortium in collaboration with the Constitutional Court of the Republic of Indonesia, Jakarta, pp. 59-60
} 
Institutional design of the state with separation of powers and checks and balances bore intersection of authority, functional relationships or relationships of coordination among state institutions. This condition has the potential to cause authority disputes between state institutions. Therefore, as a modern constitutional state (modern rule of law), the dispute settlement mechanism should be determined (canalization), so that an authority dispute among the institutions settled through diligence process of law. In the context of Indonesian constitution, Jimly Asshiddiqie stated that the process of resolving disputes over the authority of state institutions was carried out through the constitutional justice process namely the Constitutional Court ${ }^{5}$. This has been determined in Article 24C of the 1945 Constitution of the Republic of Indonesia NRI. Provisions concerning the resolution of disputes over this state institution are inseparable from issues including subjectum and objectum litis which have become jurisprudence and the institution is independent and is not a subordinate of other institutions, so there are several state institutions that cannot resolve disputes in the Constitutional Court, namely state institutions that regulate them outside the Constitution, whether regulated by law or under the law.

\section{Review of Literature}

\subsection{Legal Countries}

The rule of law was put forward by Plato and Aristotle, when they produced the concept of Nomio as a thirteen paper written in his old age. Plato argued that good governance is based on good legal arrangements. Plato's ideas about the rule of law became even more pronounced when he was supported by his student Aristotle, according to him the Nomoi concept which could be considered as the forerunner of thinking about the legal state. The ideas, ideals, or ideas of the rule of law, aside from being related to the concept of rechtsstaat and the rule of law, also relate to the concept of nomocracy which comes from the words of nomos and cratos. The words of nomocracy can be compared with demos and cratos or cratients in democracy. Nomos means the norm, while cratos is power. What is imagined as a determining factor in the exercise of power is the norm or law ${ }^{6}$.

Therefore, the term nomocracy is closely related to the idea of the rule of law or the principle of law as the highest authority. In the English term developed by AV Dicey, it can be attributed to the principle of rule of law that developed in the United States to become the jargon of the Rule of Law, and not of Man. What is really considered a leader is the law itself, not people. In Plato's book Nomoi which was later translated into English under the title The Laws, it is clearly illustrated how the idea of nomocracy actually had long been developed from the days of Ancient Greece ${ }^{7}$.

The idea of the rule of law has long been developed by philosophers from Ancient Greek times. Rule of thought is a modern idea which includes perspective and is always actual. In ancient Greece the thought of the law of the land as discussed above was developed by Plato and Aristotle was a state that stood by law that guaranteed justice for its citizens. In modern times, the concept of the rule of law in Continental Europe was developed among others by Immanuel Kant, Paul Laband, Julius Stahl, Fichte, and others using the German term, rechtsstaat. Whereas in the Anglo American tradition, the concept

\footnotetext{
${ }^{5}$ Jimly Asshiddiqie, Sengketa Kewenangan Antar Lembaga Negara, (Jakarta: Konpress, 2005), pp. 2

${ }^{6}$ Cst Kansil, Pengantar ilmu hukum dan tata hukum Indonesia, Balai Pustaka, Jakarta, 2002, pp. 3

${ }^{7}$ Ibid. pp. 6

DOI: https://doi.org/10.33258/birci.v3i1.739 
of the rule of law was developed by AV Dicey's pioneering work as The Rule of Law. According to Immanuel Kant there are two points that inspired the development of the principles of the rule of law are the problem of limitation of power by the authorities and the protection of human rights, while according to Fredrich Julius Stahl that the element of the rule of law that needs to be protected is the protection of human rights and according to him, the concept The rule of law which he calls the rechtsstaat includes four important elements, namely:

1. Protection of human rights

2. Division of power

3. Government based on law

4. State administrative justice

\subsection{State Institutions Whose Authority Is Regulated (Independent)}

Broadly speaking, the classical thinking of state administration law divides the structure of branches of state power into three branches: executive, legislative, and judiciary. These three branches of power will subsequently become a space for the formation of various state institutions, which will be the executors of these branches of power. Simply put, all institutions that are formally established to carry out state functions are an integral part of the legislative, executive or judicial branches of power ${ }^{8}$. Its development, along with the complexity of the constitutional problems faced by the state, then born many new concepts in the practice of state administration, which has implications for the increasingly varied branches of state institutional structures. This development was marked by the emergence of a number of independent state body bodies $^{9}$. The birth of these institutions is often seen as a further development of the classic concept of killing three branches of state power. In response to the inevitability of the growing need of the state to serve its citizens.

In the growth of political theory and state administration law, institutions. These independent state institutions are then categorized as a separate state institution separate from other branches of power and within the auspices of the Act. These institutions can be categorized in several degrees of independence. Starting from institutions that become independent of other state institutions and carry out certain functions permanently (state independent agencies); only supporting (state auxiliary agencies so that institutional authority is embedded to form its own rules (self-regulatory agencies), intended to perform certain supervisory functions (independent supervisory agencies), as well as institutions that perform a mixed function of regulative, administrative supervision, and law enforcement functions at once ${ }^{10}$.

\footnotetext{
8 'The concept of dividing the three branches of power (trias politica) was originally pioneered by John Locke in his Two Treatis of Government (1690) which was then also discussed by Baron Secondate Montesqiue in Spirit of the Laws (1748).

9 In theoretical discussions, these institutions are often categorized as independent regulatory boards or regulatory agencies or some call them independent regulatory independent commissions. For details see: Michael E. Milakovich and George J. Gordon, Public Administration in America, Seventh Edition, (Boston: Wadsworth and Thomson Learnng 2001), pp. 432 and 443

10 'See: Jimly Ashiddiqie, Pengantar Ilmu Hukum Tata Negara, Jakarta: RajaGrafindo Persada, 2009), pp. 338-339.
} 


\subsection{Disputes of Authority}

Understanding disputes in the Indonesian dictionary is a conflict or conflict. Conflict means the existence of opposition or disagreement between people, groups, or organizations against an object problem. According to Winardi, contradictions or conflicts that occur between individuals or groups that have the same relationship or interest in an object of ownership, which cause legal consequences between one another ${ }^{11}$. When legal disputes arise, many people assume that the only way to truly resolve them is through litigation, namely, filing lawsuits and asking for a resolution to the judiciary to voice complaints and allow a third party who is truly experienced in law to decide on a problem. However, litigation is an expensive and time-consuming business that ultimately rarely makes either party truly satisfied. There is a reason why litigation is sometimes known as the "scorched earth" option, because it can be used solely to waste enemies, rather than actually achieving some fair results ${ }^{12}$.

Seeing the source of dispute resolution in several other countries provides information that the rules and procedures of the dispute agreement will apply subject to specific or additional rules and procedures regarding dispute resolution contained in a closed agreement as identified through existing channels ${ }^{13}$. So far there are differences between the rules and procedures for special or additional set of rules that apply. In disputes involving rules and procedures of more than one closed or open agreement, if there is a conflict between specific or additional rules and procedures of the agreement that are being reviewed, and where the parties to the dispute cannot agree on rules and procedures within the time of course, since the establishment of the panel, the Chairperson of the Dispute Settlement Body in consultation with the parties to the dispute, must determine the rules and procedures that must be followed within a certain time after the request by one of the Members. The Chairperson must be guided by the principle that special or additional rules and procedures must be used where possible, and the rules and procedures set out in this Understanding must be used as far as necessary to avoid conflicts $^{14}$.

\section{Discussion}

\subsection{Welfare Detection}

Social welfare is a state of fulfilling the needs of a decent life for the community, so that they are able to develop themselves and can carry out their social functions that can be carried out by the government, regional government and the community in the form of social services which include social rehabilitation, social security, social empowerment, and social protection (Law No 11 of 2009 articles 1 and 2). Welfare is a subjective thing, so that every community or individual in it who has different guidelines, goals and ways of life will give different values about the factors that determine the level of welfare (BKKBN 1992, referenced by Nuryani 2007). Welfare according to the Central Statistics Agency (2007) is a condition in which all physical and spiritual needs of the household can

\footnotetext{
${ }^{11}$ Winardi, 'Manajemen Perilaku Organisasi', Jakarta: Pustaka Binaman Pressindo (2004). pp. 19-29

12 A'an Effendi, 'Penyelesaian Sengketa Lingkungan Melalui Peradilan Tata Usaha Negara', Perspektif (2013). 1-4

${ }^{13}$ Fabrice Lumineau and Deepak Malhotra, 'Shadow of the contract: How contract structure shapes interfirm dispute resolution', Strategic Management Journal (2011), pp. 890

${ }^{14}$ David Mason, 'Alternative dispute resolution trial', Veterinary Record (2015), pp i-iii

DOI: https://doi.org/10.33258/birci.v3i1.739 
be met according to the level of living.13 Welfare status can be measured based on the household expenditure preferences (Bappenas, 2000).

Households can be categorized as prosperous fish if the proportion of expenditure for basic needs is comparable or lower than the proportion of expenditure for non-basic needs. Conversely, households with a proportion of expenditure for basic needs are greater than expenditures for non-basic needs, can be categorized as households with low welfare status. Welfare is a system of life and social, material, and spiritual life that is followed by a sense of safety, decency and peace of mind, the household and the physical and spiritual life that enables every citizen to make an effort to meet the physical, spiritual and social needs as well as possible. For themselves, the household, and the community by upholding human rights (Rambe, 2004). Arthur Dunham in Sukoco (1991) defines social welfare as organized activities with the aim of increasing social welfare through providing assistance to people to meet the needs in several fields. Social welfare services give primary attention to individuals, groups, communities and wider population units; another opinion about social welfare was expressed also by Friedlander in Sukoco (1991):

("Social welfare is the organized system of social services and institutions, designed to help individuals and groups to attain satisfying standards of life and health, and personal and social relationships which permit them to develop their full capacities and to promote their well-being in harmony with the needs of their families and the community")

Namely that social welfare is an organized system of social services and institutions, which intends to help individuals and groups to achieve satisfactory standards of life and health, as well as personal and social relationships that enable them to develop all abilities and improve welfare in harmony with community needs.

Since Indonesia gained its independence on August 17, 1945 and the passing of the 1945 Constitution of the Republic of Indonesia as the country's foothold to provide welfare to its people. A state foundation created on the basis of enthusiasm and awareness to build a democratic country and to create a socially just, prosperous and prosperous social order together. A theory that is in line with the foundations of the Indonesian State is the theory of the Welfare State. The theory which confirms that the state whose government guarantees the welfare of the people. And to realize the people's welfare should be based on the five pillars of the state, namely: Democracy (Democracy), Law Enforcement (Rule of Law), the Protection of Human Rights (The Human Right Protection), Social Justice (Social Justice) and the Anti-Discrimination (Anti-Discrimination). The initiator of the theory of Welfare State, Prof. Mr. R. Kranenburg, revealed "that the State must actively seek prosperity, act fairly which can be felt by the entire community equally and in balance, not the welfare of certain groups but the entire people."

Theory of Welfare State is often interpreted differently by each person and the State. However, the theory outlines contains at least 4 (four) meanings, including: (i) as a well-being condition, where social welfare is a condition of meeting material and nonmaterial needs. Prosperous conditions occur when human life is safe and happy because the basic needs for nutrition, health, education, shelter, and income can be met and when humans get protection from the main risks that threaten their lives; (ii) As a social service, it generally includes five forms, namely social security, health services, education, housing and personal social services; (iii) As social benefits, social welfare is given to the poor. Because most of the beneficiaries of welfare are the poor, disabled, unemployed, which then this situation creates a negative connotation in terms of welfare, such as poverty, laziness, dependency, and so on; (iv) As a planned process or business, a process 
carried out by individuals, social institutions, communities and government bodies to improve the quality of life through the provision of social services and social benefits.

Understanding of the Welfare State (Welfare State) cannot be separated from the four definitions of welfare above. Welfare State is very closely related to social policy, which in many countries includes government strategies and efforts to improve the welfare of its citizens, especially through social protection which includes social security (both in the form of social assistance and social insurance) and nets social safety (social safety net). In its implementation, the Government of Indonesia seeks to create prosperity for all Indonesian people as mandated in the 1945 Constitution which expressly mandates social welfare as the highest priority of the country's public policy. Social welfare is contained in the 1945 Constitution which among others states, that the economy is based on the principle of kinship, finances basic education, develops a social security system for all Indonesians, empowers weak and disadvantaged people and provides health care facilities and adequate public service facilities. The Indonesian government is clearly mandated to place the interests of the people above the interests of individuals.

\subsection{Paradigm: Dispute Analysis of Authority of State Agencies}

Efforts to understand the potential disputes over the authority of state institutions based on legislation that are possible can arise, it is necessary for us to have a special view and normative assumptions while dividing some potential conflicts from the side of the settlement arrangements, including:

First, there is an institution that is not possible potential / conflict of authority with other institutions because it has special authority, the authority handling by the Commission which are Privilege the legal process of corruption that allows for other agencies can not intervene in the authority of the Commission in conducting legal process on a case. Mentioned in Law of the Republic of Indonesia Number 30 Year 2002 Regarding Corruption Eradication Commission Article 8 paragraph (1) in carrying out supervisory duties, the Corruption Eradication Commission has the authority to conduct surveillance, research, or study of other authorized institutions relating to eradicating corruption and implementing agencies public services, and in Article 8 paragraph (2). The $\mathrm{KPK}$ is also authorized to take over investigations or prosecutions of perpetrators of criminal acts of corruption that are being carried out by the police or prosecutors. Then in Article 8 paragraphs (3) and (4) it states that in the case that the KPK takes over investigation or prosecution, the police and prosecutors must submit the suspect and all case files along with evidence and other documents accompanied by minutes of the surrender. Based on this provision, it is highly unlikely that a state institution which has supervision authority will experience a conflict or potential dispute over authority with other legal institutions, because it has supervision authority.

Second, there is the authority of an institution whose decision may have the potential to cause conflict or can be disputed by other institutions but already has a regulated settlement pathway, for example the authority of the KPPU (business competition supervision commission ) whose organizational decisions can be challenge/appealed to the court forum in settlement business competition dispute in Indonesia as explained in Act Number 5 of 1999 concerning Prohibition of Monopolistic Practices and Unfair Business Competition article 44 paragraph (2) that Business Actors may submit objections to the District Court no later than 14 (fourteen) days after receive notification of the decision. The explanation above explained that the potential for conflict might occur if the business actors felt objected and the law regulates the parties who objected to the KPPU's 
decision to submit it to the district court forum, and this meant that the potential for conflict that existed in the KPPU's institution had been set up. .

Third, is the authority of state institutions that have the potential to conflict with authority but there are no rules to resolve them, for example the authority of Komnas HAM in determining an event is a felony of human rights crimes regulated in Law Number 26 of 2000 concerning Human Rights Courts article 18 paragraph (1) i.e. Investigation of gross human rights violations carried out by the National Human Rights Commission, which then may experience potential conflicts with the authority of the Police in Law Number 2 of 2002 concerning the Republic of Indonesia National Police article 14 paragraph (1) point g. namely the Indonesian National Police conduct an investigation and investigation of all criminal acts in accordance with the criminal procedure code and other laws and regulations. If later in the same case handled by the National Human Rights Commission and then the Police declared the incident was an ordinary crime which is the domain of the police's authority to conduct investigations and investigations, then this would be a conflict of authority between the National Human Rights Commission and the Police in the matter of determining a crime event is gross human rights violations or ordinary criminal acts, and to date there are no provisions in the legal regulations governing how to resolve disputes over authority over potential conflicts.

\subsection{Criticism Resolution of the Dispute over the Authority of State Institutions Currently in Force}

Concerning the authority of the Constitutional Court is regulated in Article 24C paragraph (1) of the 1945 Constitution of the Republic of Indonesia which stipulates that "the Constitutional Court has the authority to adjudicate at the first and last level whose decisions are final to test the law against the Constitution, decide upon disputes over the authority of the state institution whose authority provided by the Constitution, decides the dissolution of political parties, and resolves disputes over the results of general elections". The authority of the Constitutional Court is also regulated in Article 10 paragraph (1) of Law Number 24 of 2003 concerning the Constitutional Court and Article 29 of Law Number 48 of 2009 concerning Judicial Power.

Based on the provisions of Article 24C paragraph (1) of the 1945 Constitution of the Republic of Indonesia, Article 10 paragraph (1) of the Constitutional Court Law, and Article 29 of Law Number 48 of 2009 concerning Judicial Power, the request for a dispute over the authority of a state institution can only be made if fulfilled 2 (two) cumulative conditions. The three conditions are: 1) the applicant is a state institution referred to in the 1945 NRI Constitution; dab 2) the disputed authority is the authority granted by the 1945 Constitution of the Republic of Indonesia. This is in line with the provisions of Article 61 paragraph (1) of the Constitutional Court Law which stipulates that "the Petitioner is a state institution whose authority is granted by the Indonesian Constitution of the Year 1945 which has a direct interest in the disputed authority. According to Jimly Asshidiqqie, that in the dispute of authority between state institutions whose authority is given by the constitution there are two conditions that must be met, namely the existence of constitutional authority determined by the Constitution and the dispute over authority arises due to differences in interpretation between two or more related state institutions ${ }^{15}$.

\footnotetext{
${ }^{15}$ Jimly Asshidiqqie dalam Abdul Latif, Fungsi Mahkamah Konstitusi, (Yogyakarta: Total Media, 2009), pp. 152
} 
The first requirement is regarding subjectum litis or who has a legal standing to submit an application to the Constitutional Court. For subjectum litis, it is required that the said state institution must be a state institution directly mentioned in the 1945 Constitution of the Republic of Indonesia or an institution commonly referred to as constitutional organ. State institutions that are formed based on laws or other laws and regulations cannot be classified as subjectum litis in resolving disputes over the authority of state institutions to the Constitutional Court. The second condition is objectum litis which requires that "the authority of the said state institution must be the authority granted by the 1945 Constitution of the Republic of Indonesia". To be able to become an applicant in a state agency dispute, the two conditions must be absolute cumulative. In the 1945 Constitution of the Republic of Indonesia, there are some state institutions which are mentioned but not accompanied by the formulation of their authority, and there are also state institutions whose authority is formulated, but the institution is not explicitly mentioned in the 1945 Constitution of the Republic of Indonesia.

Seeing the provisions of the requirements regarding subjectum and objectum litis above, then based on Article 2 paragraph (1) of the Constitutional Court Regulation No. 08 / PMK / 2006 it is determined that those who can become applicants and petitioners in disputes over the authority of state institutions are 1) the House of Representatives (DPR );2) Regional Representative Council (DPD); 3) People's Consultative Assembly (MPR); 4) President; 5) Financial Examination Board (BPK); 6) Local Government; or 7) Other state institutions whose authority is granted by the 1945 Constitution of the Republic of Indonesia. During this time, the Constitutional Court's decision always uses 2 (two) conditions stated above namely subjectum litis must be a state institution formed based on the 1945 Constitution of the Republic of Indonesia and objectum litis must the authority granted by the 1945 Constitution of the Republic of Indonesia. No. 004 / SKLN-IV / 2006 has determined the criteria of objectum litis, namely: (a) the authority of state institutions is explicitly granted by the constitution; (b) that authority is implicitly delegated by the Constitution to be regulated further in law; and (c) there must be an appropriate relationship between the authority specified in the Constitution implicitly and the law that further regulates that authority. Both conditions are applied by the Constitutional Court in an absolute cumulative, not optional. So, even if the subjectum litis is fulfilled, but the objectum litis is not fulfilled, the request is always unacceptable ${ }^{16}$.

\section{Conclusion}

Limitation of the Constitutional Court is only given the authority to resolve disputes over the authority of state institutions granted by this Constitution which then creates some free space in resolving disputes over state institution authority, because what then arises the question in question is what about the disputes of authority between state institutions whose authority given by law. This becomes necessary, because it is not impossible that there will be a dispute over authority in carrying out the functions of the said state institution, because the intersection of authority must be experienced by layers of state institutions under the Constitution such as state institutions based on the law.

It also needs to get attention, because with the development of the task of the state to prosper the people, running straight with the birth of independent state institutions that

${ }^{16}$ F.A.M. Stroink on Abdul Rasyid Thalib, Authority of the Constitutional Court and Its Applications in the Indonesian Administrative System, (Bandung: Citra Aditya Bakti, 2006) 
solely respond to the needs of the development of state institutions in accordance with the demands of the times which then one with another has a functional relationship, with If there is a functional relationship, it does not rule out disputes of authority between state institutions at the level of the law. On the basis of a modern legal state, disputes over the authority of state institutions that are formed based on the law, need to be channeled to settle so that they remain based on due process of law and there are no rules in the process of resolving disputes over the authority of state institutions in the Law. Based on the potential conflicts over authority disputes above which have been divided into 3 categories, it is deemed necessary to find a solution so that it does not become a problem in the future of state institutions because the rapid formation of new state institutions under the law does not rule out the possibility of causing additional conflicts of authority disputes what happened and even what was felt to be a fairly urgent legal problem when it turned out that the resolution of the dispute that was possible also occurred was not regulated or included/included in the act governing the formation of the state institution.

\section{References}

Ali Safa'at, M Sengketa Kewenangan Antar Lembaga Negara, Academia.Edu/6376671/ Sengketa

Asshiddiqie, Jimly, (2017). 'Analisis Penguatan Majelis Permusyawaratan Rakyat Sebagai Lembaga Parlemen Dalam Sistem Ketatanegaraan Di Indonesia', Jurnal Hukum \& Pembangunan, [Identitas://Doi.Org/10.21143/Jhp.Vol41.No4.258].

Asshiddiqie, Jimly, (2017). 'Cita Ketuhanan Dalam Hukum Di Indonesia Dan Nisbah Antara Hukum Islami Dengan Hukum Adat', Jurnal Hukum \& Pembangunan, [Identitas://Doi.Org/10.21143/Jhp.Vol14.No4.1046].

Asshiddiqie, Jimly, (2002). 'Gagasan Negara Hukum Indonesia', Gagasan Negara Hukum Indonesia, (Doi.Org/10.1522/1389686].

Asshiddiqie, Jimly, (2006). 'Ideologi, Pancasila, Dan Konstitusi', Jaringan Informasi Hukum.

Asshiddiqie, Jimly, (2017). 'Kedudukan Dan Peranan Hukum Tata Negara Dalam Pembangunan', Jurnal Hukum \& Pembangunan, [Identitas://Doi.Org/10.21143/Jhp.Vol25.No2.474].

Asshiddiqie, Jimly, (2016). 'Mahkamah Konstitusi Dan Pengujian Undang-Undang', Jurnal Hukum Ius Quia Iustum, [Identitas://Doi.Org/10.20885/Iustum.Vol11.Iss27.Art1].

Asshiddiqie, Jimly, (2017). 'Mempopulerkan Kembali Gagasan Republik Di Antara CitaCita Demokrasi Dan Nomokrasi', Jurnal Hukum \& Pembangunan, [Identitas://Doi.Org/10.21143/Jhp.Vol25.No4.482].

Asshiddiqie, Jimly, (2016). 'Pemilihan Langsung Presiden Dan Wakil Presiden', Unisia.

Asshiddiqie, Jimly, (2017). 'Telaah Kritis Mengenai Perspektif Historis-Evolusioner Dalam Studi Hukum Dan Perkembangan Sosial Di Indonesia', Jurnal Hukum \& Pembangunan.

Asshiddiqie, Jimly, (2006). "Konstitusi dan Amandemen Konstitusi”, (Makalah disampaikan pada Kuliah Umum di Fakultas Ilmu Sosial dan Ilmu Politik Universitas Gadjah Mada, Yogyakarta 29 April 2006)

Asshiddiqie, Jimly, (2005). Format Kelembagaan Negara dan Pergeseran Kekuasaan Dalam UUD 1945, (Yogyakarta: FH UII Press). 
Asshiddiqie, Jimly, (2004). Menjaga Denyut Nadi Konstitusi: Refleksi Satu Tahun Mahkamah Konstitusi, (Jakarta: Konstitusi Press), (Editor Refly Harun, et al).

Asshiddiqie, Jimly, (2006). Pembangunan hukum dan penegakkan hukum di Indonesia, lustrum XI fakultas hukum UGM, Yogyakarta, 16 februari 2006.

Asshiddiqie, Jimly, (2010). Perkembangan \& Konsolidasi Lembaga Negara Pasca Amandemen, (Jakarta: Sinar Grafika).

Asshiddiqie, Jimly, (2004) Perkembangan Ketatanegaraan Pasca Perubahan UUD 1945 dan Tantangan Pembaharuan Pendidikan Hukum Indonesia, Makalah disampaikan dalam Seminar Nasional "Perkembangan Ketatanegaraan Pasca Perubahan UUD dan Lokakarya Pembaharuan Kurikulum Pendidikan Tinggi Hukum Indonesia", diselenggarakan oleh Asosiasi Pengajar HTN dan HAN, Jakarta, 7 September 2004,

Asshiddiqie, Jimly, (2005). Sengketa Kewenangan Antar Lembaga Negara, (Jakarta: Konpress,)

Brian Thompson tentang Konstitusi Inggris, "In other words the British constitution was not made, rather it mhas grown".

Brian Thompson, Textbook on Constitutional and Administrative Law, edisi ke-3,

Cst Kansil. (2002). Pengantar ilmu hukum dan tata hukum Indonesia, Balai Pustaka, Jakarta.

D. Duchacek, -Constitution and Constitutionalism\| dalam Bogdanor, Vernon

Dahlan Thaib, Jazim Hamidi, and Ni'matul Huda. (2005). Teori Dan Hukum Konstitusi, Raja Grafindo Persada: Jakarta.

Effendi, A'an, (2013). 'Penyelesaian Sengketa Lingkungan Melalui Peradilan Tata Usaha Negara', Perspektif.

F.A.M. Stroink in Abdul Rasyid Thalib, (2006). Wewenang Mahkamah Konstitusi dan Aplikasinya dalam Sistem Ketatanegaraan Republik Indonesia, (Bandung: Citra Aditya Bakti)

Firmansvah Arifin, et all, (2005), Lembaga Negara dan Sengketa Kewenangan Antarlembaga Negara, Konsorsium Reformasi Hukum Nasional bekerjasama dengan Mahkamah Konstirust Republik Indonesia, Jakarta

Firmansyah Arifin et al. (Tim Peneliti), (2005). Lembaga Negara dan Sengketa Kewenangan Antarlembaga Negara, KRHN bekerjasama dengan Mahkamah Konstitusiri di dukung oleh The Asia Foundation dan USAID, Jakarta.

Friedrich, C.J., (1963). Man and His Government, (New York: McGraw-Hill).

Fuqoha, Fuqoha, (2018). 'Pengisian Jabatan Presiden Dan Presidential Threshold Dalam Demokrasi Konstitusional Di Indonesia', Ajudikasi: Jurnal Ilmu Hukum, 2018 [Identitas://Doi.Org/10.30656/Ajudikasi.V1i2.495].

Girindro Pringgodigdo, (1994). "Kebijaksanaan, Hirarkhi Perundang-undangan dan Kebijakan dalam Konteks Pengembangan Hukum Administrasi Negara di Indonesia", (Pidato Pengukuhan Guru Besar Fakultas Hukum Universitas Indonesia, 16 November 1994),

H.F. Abraham Amos, (2005). Sistem Ketatanegaraan Indonesia (Dari Orla, Orba sampai reformasi), Telaah Sosiologi Yuridis dan Yuridis Pragmatis Krisis Jati Diri Hukum Tata Negara Indonesia, (Jakarta: Rajawali Press,).

Husda, H., and Zubaidah. (2018). Role Optimization of Indigenous Institutions for Case of Violence Against Women and Children (Analysis Study in Aceh and Padang Provinces). Budapest International Research and Critics Institute (BIRCI-Journal), 170-180.

UU, (2004). 'Undang-Undang No 32 Tahun 2004 Tentang Pemerintah Daerah', Dpr. 
UUD RI, Undang-Undang Dasar Tahun 1945.

Warjiati, Sri, (2018) 'Sistem Ketatanegaraan Indonesia Pasca Amandemen Uud 1945', AlDaulah: Jurnal Hukum Dan Perundangan Islam, [Identitas://Doi.Org/10.15642/Ad.2012.2.2.185-207].

Widayati, Absori, and Aidul Fitriciada Azhari, (2014) 'Rekonstruksi Kedudukan Ketetapan Mpr Dalam Sistem Ketatanegaraan Indonesia', Media Hukum.

Winardi, (2004). 'Manajemen Perilaku Organisasi', Jakarta: Pustaka Binaman Pressindo. 